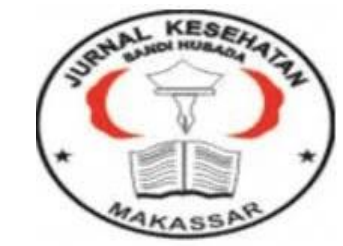

\author{
Jurnal Ilmiah Kesehatan Sandi Husada
}

hhttps://akper-sandikarsa.e-journal.id/JIKSH

Volume 9, Nomor 1, Juni 2020, pp;560-565

p-ISSN: 2354-6093 dan e-ISSN: 2654-4563

DOI: $10.35816 /$ jiskh.v10i2.342

\title{
Faktor yang Berhubungan dengan Tradisi Masyrakat dalam Menghadapi Kehamilan dan Persalinan Di Desa Welado
}

Factors Related to Community Tradition in Facing Pregnancy and Labor in Welado Village

\author{
Mustar Mustar \\ DIII Kebidanan,Akademi Kebidanan Bina Sehat Nusantara
}

\section{Artikel info \\ Artikel history:}

Received; Mei 2020

Revised: Juni 2020

Accepted; Juni2020

\begin{abstract}
Abstrak
Terdapat berbagai macam tradisi yang sering ditemui dimasyarakat termasuk Tradisi dalam bidang kesehatan yang berkaitan dengan kehamilan dan persiapan persalinan, tujuan penelitian untuk mengetahui faktor yang berhubungan dengan tradisi masyarakat dalam menghadapi kehamilan dan persalinan Metode Penelitian dalam penelitian ini adalah Survey Analitik dengan rancangan Cross Sectional Study. Jumlah sampel dalam penelitian ini sebanyak 30 sampel. Hasil Penelitian menunjukkan bahwa terdapat Hubungan pengetahuan ibu hamil dengan Tradisi dalam menghadapi kehamilan dengan nilai $\rho=0,008$, dan terdapat hubungan pengetahuan ibu bersalin dengan Tradisi dalam menghadapi kehamilan dengan nilai $\rho=0,007$. Adapun Hubungan Pendidikan dengan Tradisi dalam menghadapi kehamilan dengan nilai $\rho=0,002$, Hubungan pendidikan dengan tradisi menghadapi persalinan dengan nilai $\rho=0,029$. Penelitian ini dapat disimpulkan bahwa terdapat Hubungan antara Pengetahuan dan Pendidikan ibu hamil dan Ibu Bersalin dengan Tradisi dalam menghadapi kehamilan dan Persalinan
\end{abstract}

\section{Abstract}

There are various kinds of traditions that are often encountered in the community, including traditions in the health sector related to pregnancy and childbirth preparation, the purpose of research to determine factors related to community traditions in dealing with pregnancy and childbirth. The research method in this study is Analytical Survey with Cross Sectional Study design. The number of samples in this study were 30 samples. The results showed that there is a relationship between knowledge of pregnant women with tradition in dealing with pregnancy with a value of $\rho=0.008$, and there is a relationship between knowledge of maternity with tradition in dealing with pregnancy with a value of $\rho=0.007$. The Relationship of Education with Tradition in dealing with pregnancy with a value of $\rho=0.002$, The relationship of education with the tradition of facing childbirth with a value of $\rho=0.029$. This study can be concluded that there is a relationship between knowledge and education of pregnant women and maternity with tradition in dealing with pregnancy and childbirth 


\begin{tabular}{lr} 
Keywords: & Corsponden author: \\
Knowledge; & Email: mustarb01@gmail.com \\
Education; & \\
Comunity tradition; & artikel dengan akses terbuka dibawah lisensi BCC BY NC ND-4.0 \\
\hline \hline
\end{tabular}

\section{Pendahuluan}

Tradisi merupakan produk kebudayaan, atau pengembangan dari aktivitas manusia sebagai makhluk pencipta kebudayaan. Dengan demikian tradisi bisa dianggap sebagai suatu sarana kebudayaan bagi manusia dan dengan sarana itu dia mampu menyesuaikan diri dengan pengalaman- pengalamannya dalam keseluruhan lingkungan hidupnya. Dalam lingkungan tersebut pikiran, perasaan dan perbuatan manusia terhadap perasaannya berada di luar jangkauan pengalaman- pengalamannya sehari-hari dengan dirinya sendiri, teman-temannya, dan dengan dunia nyata yang telah membuat kita percaya. (Yanti, 2008). Terdapat berbagai macam tradisi yang sering ditemui, termasuk dalam bidang kesehatan. Walaupun dunia kesehatan sudah semakin maju, tetapi ada beberapa kelompok masyarakat di berbagai negara yang mempertahankan budaya lokal. Tradisi dalam bidang kesehatan sering berkaitan dengan kehamilan, persalinan, masa nifas/postpartum dan Bayi Baru lahir.

Berdasarkan data World Health Organization (WHO) tahun 2015 Angka kematian ibu di dunia pada Tahun 2015 adalah 216 per 100.000 kelahiran hidup diperkirakan jumlah kematian ibu adalah 303.000 kematian dengan jumlah tertinggi berada di negara berkembang yaitu sebesar 302.000 kematian. Data menurut kemenkes RI pada tahun 2016 jumlah ibu hamil diperkirakan sebanyak (35,20\%), tahun 2017 jumlah ibu hamil diperkirakan sebanyak $(37,36 \%)$ dan pada tahun 2018 jumlah ibu hamil diperkirakan sebanyak (17,3\%). Berdasarkan SDKI tahun 2016 jumlah ibu bersalin di Indonesia sebesar 4.125. 250 orang pertahun, pada tahun 2017 jumlah ibu besalin di indonesia dipekirakan sebesar 5.112.269 orang pertahun. Sedangkan tahun 2018 jumlah ibu bersalin di indonesia sebesar 6.345.000 orang pertahun. (SDKI, 2019).

Menurut profil dinas kesehatan Provinsi Sulawesi Selatan pada tahun 2016 jumlah ibu hamil sebanyak (78,7\%). Pada tahun 2017 jumlah ibu hamil Sebanyak (40,93\%). Pada tahun 2018 jumlah ibu hamil sebanyak (70,93\%). Berdasarkan data kesehatan Provinsi Sulawesi Selatan tahun 2016 jumlah ibu bersalin sebesar 151,450 orang pertahun. Pada tahun 2017 jumlah ibu bersalin sebesar179.468 orang pertahun. Sedangkan pada tahun 2018 jumlah ibu bersalin sebesar 180. 570 orang pertahun. (Dinkes Sul-Sel, 2019). Dari data Dinas Kesehatan Kabupaten Bone pada tahun 2016, jumlah kunjungan ibu hamil sebanyak 15.200 orang. Pada tahun 2017 jumlah kunjungan ibu hamil sebanyak 15.113 orang, sedangkan tahun 2018 jumlah kunjungan ibu hamil sebanyak 14.911 orang. Dari data Dinas Kesehatan Kabupaten Bone tahun 2016, jumlah ibu bersalin sebanyak 13.791 orang. cakupan persalinan mengalami peningkatan setiap tahun, persalinan normal sebanyak $84,67 \%$, sedangkan persalinan abnormal sebanyak $15.32 \%$. sedangkan selama tahun 2017 ini, tedapat 8 angka kematian ibu khusus orang bone dan pada tahun 2019 sebanyak 14 orang, umumnya mereka meninggal pada saat persalinan maupun pasca pesalinan dengan paritas yang cukup tinggi. (Dinkes Kab. Bone, 2018) Berdasarkan data yang diperoleh dari UPTD Puskesmas Ajangale pada tahun 2016 jumlah AKI sebanyak 30 orang dan pada tahun 2017 jumlah AKI sebanyak 37 orang. 
Sedangkan pada tahun 2018 diperoleh jumlah AKI sebanyak 40 orang. (Data UPTD Puskesmas Ajangale, 2018). Berdasarkan uraian diatas masih tingginya angka kematian ibu pada saat hamil maupun bersalin yang disebabkan berbagai faktor baik faktor internal maupun eksternal dan berbagai upaya yang telah dilakukan untuk menekan kasus tersebut maka dari itu peneliti tertarik untuk mengkaji hal tersebut melalui penelitian yang berjudul faktor yang berhubungan dengan tradisi masyarakat dalam menghadapi kehamilan dan persalinan di Desa welado Kec.Ajangale.

\section{Metode}

Jenis penelitian yang digunakan dalam penelitian ini adalah Survey Analitik dengan rancangan Cross Sectional Study. Tujuan penelitian ini untuk melihat Faktor yang berhubungan dengan tradisi masyrakat dalam menghadapi kehamilan dan persalinan. Penelitian ini dilaksanakan di Desa welado Kecamatan Ajangale dengan melibatkan 30 responden dimana ibu hamil sebanyak 15 orang dan ibu bersalin 15 orang, penarikan sampel menggunakan probability sampling dengan metode Total sampling. Variabel dependen dalam penelitian ini adalah Tradisi dalam menghadapi kehamilan dan persalinan dan variabel independen dalam penelitian ini adalah, Pengetahuan, Pendidikan dan Tradisi Masyarakat.

Pengumpulan data dilakukan dengan mengumpulkan ibu hamil dan ibu bersalin di salah satu tempat dan membagikan kuesioner. Data diuji dengan menggunakan distribusi frekuensi variabel independen dan dependen. Analisa Bivariat digunakan untuk melihat hubungan Pengetahuan, Pendidikan dan Tradisi masyarakat dalam menghadapi kehamilan dan persalinan dengan menggunakan uji statistik Chi-Square dengan menggunakan komputerisasi.

\section{Hasil Dan Pembahasan}

Tabel. 1 Analsis hubungan antara pengetahuan, pendidikan dengan tradisi masyarakat dalam menghadapi kehamilan di Desa Welado Kecamatan Ajangale

\begin{tabular}{|c|c|c|c|c|c|c|c|c|}
\hline \multirow{3}{*}{ Pengetahuan } & \multicolumn{6}{|c|}{ Tradisi } & \multirow{3}{*}{ p-Value } & \multirow{3}{*}{$\mathrm{a}$} \\
\hline & \multicolumn{2}{|c|}{ Baik } & \multicolumn{2}{|c|}{ Buruk } & \multicolumn{2}{|c|}{ Total } & & \\
\hline & $\mathrm{n}$ & $\%$ & $\mathrm{~N}$ & $\%$ & $\mathrm{n}$ & $\%$ & & \\
\hline Baik & 8 & 53 & 0 & 0 & 8 & 54 & & \\
\hline Cukup & 2 & 13 & 3 & 20 & 5 & 33 & 0,008 & 0,05 \\
\hline Kurang & 0 & 0 & 2 & 13 & 2 & 13 & & \\
\hline Total & 10 & 66 & 5 & 33 & 15 & 100 & & \\
\hline \multicolumn{9}{|l|}{ Pendidikan } \\
\hline SD & 7 & 46 & 0 & 0 & 7 & 47 & \multirow{5}{*}{0,002} & \multirow{5}{*}{0,05} \\
\hline SMP & 3 & 20 & 0 & 0 & 3 & 20 & & \\
\hline SMA & 0 & 0 & 3 & 20 & 3 & 20 & & \\
\hline PT & 0 & 0 & 2 & 13 & 2 & 13 & & \\
\hline Total & 10 & 66 & 5 & 33 & 15 & 100 & & \\
\hline
\end{tabular}

Sumber: Data primer 2019 
Berdasarkan hasil penelitian diketahui bahwa tertinggi dalam kategori pengetahuan baik dengan tradisi baik sebanyak 8 responden (53\%). Sedangkan terendah dalam kategori pengetahuan cukup dengan tradisi buruk sebanyak 3 responden (20\%). Berdasarkan hasil uji chi square test didapatkan $\mathrm{p}$-value $=0,008 \mathrm{P}<0,05$ yang berarti Ha diterima dan $\mathrm{H} 0$ ditolak sehingga dapat disimpulkan bahwa ada hubungan antara pengetahuan dengan tradisi masyarakat dalam menghadapi kehamilan.

Berdasarkan Notoatmodjo (2010) Pengetahuan merupakan kesan di dalam pikiran manusia sebagai hasil tahu dan ini terjadi setelah orang melakukan pengindraan terhadap suatu objek tertentu. Pengetahuan tentang persalinan yang dimiliki ibu hamil akan menentukan cara pikir dan cara pandangnya tentang persalinan. Semakin banyak pengetahuan yang dimiliki ibu hamil tentang persalinan akan membentuk pikiran yang positif tentang persalinan sehingga ibu lebih siap menghadapi persalinan. Ibu akan menyambut persalinan dengan mempersiapkan segala sesuatu yang diperlukan termasuk menjaga kehamilannya dengan baik dengan melakukan pemeriksaaan rutin pada tenaga kesehatan. Ibu akan mematuhi anjuran dari tenaga kesehatan. karena ibu tau bahwa persalinan harus disiapkan sejak masa kehamilan, Pengetahuan dipengaruhi oleh umur, pengalaman, pendidikan, lingkungan, dan sumber informasi. Karakteristik berbeda yang dimiliki responden menjadi faktor yang dapat mempengaruhi hasil jawaban kuesioner sehingga didapatkan bahwa pengetahuan responden ada yang baik dan cukup. Tidak semua ibu memiliki pengetahuan baik tentang persalinan karena ini merupakan pengalaman kehamilan yang pertama kalinya. Latar belakang lingkungan dan sumber informasi yang berbeda membuat hasil jawaban responden beragam. Tidak ada responden yang memiliki pengetahuan buruk tentang persalinan karena tingkat pendidikan responden adalah SMA. Sehingga kesadaran untuk memperoleh informasi lebih baik. Kemajuan informasi menempati peran penting dalam mempengaruhi pengetahuan seseorang dimasyarakat termasuk pada ibu hamil. Mudahnya akses internet, media-media elektronik dan cetak berpengaruh besar terhadap peningkatan informasi dan pengetahuan sehingga dengan mudah mengubah perilaku masyarakat dari yang belum memahami menjadi paham dan menerapkannya dalam kehidupannya. Ibu hamil dapat dengan mudah mengakses informasi tentang kehamilan dan persalinannya disamping informasi yang didapatkannya dari tenaga kesehatan saat melakukkan antenatal care. Selain itu, untuk mendapatkkan informasi guna meningkatkan pengetahuan persiapan persalinan, ibu hamil dapat bertanya kepada orang tua/ ibunya serta orang-orang disekitarnya yang sudah berpengalaman.

Hal ini tidak sejalan dengan Penelitian Mara ipa dimana menemukan praktik budaya sebagai pendukung kepatuhan pada pimpinan adat (kokolot), perayaan tradisi sebagai media promosi program kesehatan, pemanfaatan obat tradisional, pola pemukiman secara kluster. Faktor yang membahayakan tidak ada pemeriksaan medis selama kehamilan. persalinan dan nifas, prosesi melahirkan secara mandiri, tempat persalinan situasional (saung/rumah), lama waktu menunggu paraji, pemotongan tali pusat, usia pertama kali melahirkan, melakukan aktivitas berat, larangan menggunakan pakaian dalam dan pembalut wanita. 
Berdasarkan hasil analsisi diketahui bahwa tertinggi dalam kategori pendidikan menengah (SMP) sebanyak 4 responden (26\%). Sedangkan terendah dalam kategori pendidikan dasar (SMA) sebanyak 2 orang (13\%). Berdasarkan hasil uji chi square test didapatkan $\mathrm{p}$-value $=0,029 \mathrm{P}<0,05$ yang berarti Ha diterima dan $\mathrm{H} 0$ ditolak sehingga dapat disimpulkan bahwa ada hubungan antara pendidikan dengan tradisi masyarakat dalam menghadapi Persalinan.

Hal ini sejalan dengan teori Notoatmodjo (2013), sikap dan tindakan seseorang yang didasari oleh pendidikan akan lebih langgeng. Tingkat pendidikan ibu akan menentukan sikap dan tindakannya dalam menghadapi berbagai masalah khususnya masalah kesehatan. Ibu yang berpendidikan tinggi semakin mudah menyerap informasi sehingga memiliki persepsi yang lebih baik dibandingkan dengan yang berpendidikan rendah. Orang yang berpendidikan tinggi akan memberikan respon yang lebih rasional terhadap informasi yang datang dan akan berperilaku yang lebih banyak memberikan keuntungan. Hal ini sejalan dengan teori menurut Sukmadinata (2013), bahwa pendidikan bukan merupakan satu-satunya faktor eksternal yang mempengaruhi pengetahuan seseorang, faktor eksternal yang mempengaruhi pengetahuan seseorang, selain pendidikan adalah paparan media masa dimana seseorang yang mempunyai sumber informasi yang lebih banyak melalui berbagai media baik cetak maupun elektronik, akan mempunyai pengetahuan yang lebih luas dibandingkan dengan orang yang tidak terpapar informasi media selain itu faktor ekonomi juga mempengaruhi tingkat pengetahuan seseorang, dimana keluarga dengan status ekonomi baik lebih mudah mencukupi kebutuhannya dibandingkan dengan status ekonomi rendah; faktor hubungan sosial dan pengalaman juga mempengaruhi pengetahuan seseorang, dimana seseorang yang dapat besinteraksi secara kontinyu akan lebih banyak mendapat informasi, serta pengalaman seseorang tentang suatu hal dapat menambah pengetahuan mengenai sesuatu yang bersifat non formal.

Penelitian ini sejalan dengan penelitian yang dilakukan oleh Dirbadiyah (2009) yang menyatakan bahwa ada hubungan antara pendidikan dengan sikap ibu bersalin. Hal ini dikarena pendidikan yang rendah menyebabkan pengetahuan mereka tentang hal-hal ataupun risiko yang berhubungan dengan persalinan juga rendah. Hal ini juga sejalan dengan penelitian Nelly Indrasari (2014), yang menyakan bahwa ada hubungan yang bermakna antara pendidikan dengan persalinan oleh dukun bayi di Desa Negeri Agung Kecamatan Talang Padang Kabupaten Tanggamus Tahun 2012. Latar belakang pendidikan seseorang dapat mempengaruhi bahkan menentukan jangkauan ke masa depan. Dengan pendidikan yang rendah menyebabkan ibu masih melakukan persalinan oleh dukun bayi. Hal ini akan lebih nampak bila ibu tidak mempunyai akses terhadap informasi seperti mendengarkan penyuluhan dan radio, menonton televisi, membaca koran maupun mendapat informasi dari teman atau tetangga. Mereka yang berpendidikan lebih tinggi cenderung lebih banyak terpapar berbagai sumber informasi dan karenanya menjadi lebih kritis dibandingkan mereka yang tidak atau kurang terpapar. Akibat kurangnya keterpaparan terhadap berbagai sumber informasi, maka dalam membedakan tradisitradisi baik dan buruk, responden yang berpendidikan rendah cenderung tidak bersikap kritis dan biasanya mengikuti adat kebiasaan di desa tersebut yang menyangkut kehamilan dan persalinan. 


\section{Simpulan Dan Saran}

Dapat disimpulkan bahwa terdapat hubungan antara pengetahuan, pendidikan dan tradisi masyarakat dalam menghadapi kehamilan dan persalinan, adapun saran Penelitian selanjutnya diharapkan menggunakan Metodelogi penelitian yang berbeda yaitu penelitian kualitatif dengan menggunakan sampel yang lebih besar lagi.

\section{Daftar Rujukan}

Abdullah, A.2008, Definisi dan Jenis Pengetahuan. http ://www.Referensi assayari Abdullah.com

Arikunto,Suharsimi, 2010. Prosedur Penelitian Suatu Pendekat Praktik. Jakarta: Edisi revisi VI . PT. Rineka cipta.

Arikunto, S. 2010, Prosedur Penelitian. Rineka Cipta.Jakarta

Hidayat, 2009. Metodelogi Penelitian Keperawatan dan Teknik Analisa Data, Jakarta: Salemba Medika

Johariyah, dkk. 2010. AsuhanKebidanan Persalinan \& Bayi Baru Lahir. Jakarta: CV. Trans Info Media.

Marmi. 2012. Intranatal Care Asuhan Kebidanan Pada Persalinan. Yogyakarta: Pustaka Pelajar.

Mara ipah. (2016). Praktik budaya perawatan dalam kehamilan persalinan dan nifas pada etnik baduy Dalam. Badan penelitian dan pengembangan kesehatan

Nelli sari. (2014). Hubungan faktor sosial budaya dengan persalinan oleh dukun bayi Di Desa Negeri Agung Kecamatan Talang Padang, Tanggamus. Jurnal Kesehatan Metro Sai Wawai Volume VII No.2 Edisi Desember 2014, ISSN: 19779-469X

Notoatmodjo. 2010. Metodologi Penelitian. Jakarta: Rineka Cipta

Nursalam. 2011. Konsep dan Penerapan Metodologi Penelitian Ilmu Keperawatan. Jakarta: Salemba Medika

Prawirohardjo, 2009. Ilmu Kebidanan. Jakarta: Yayasan Bina Pustaka.

Putranti. (2014). Hubungan Pengetahuan Dan Sikap Tentang Persalinan Dengan Kesiapan Primigravida Menghadapi Persalinan. Skripsi. STIkes Yogyakarta

Rukiyah,dkk. 2011. Asuhan Kebidanan Patologi Kebidanan. Jakarta: CV. Trans Info Media.

Rohani, 2011. Asuhan pada Masa Persalinan. Jakarta: Salemba Medika

Saifuddin AB. 2010. Buku Acuan Nasional Pelayanan Kesehatan Maternal Dan Neonatal. Jakarta: Yayasan Bina Pustaka Sarwono Prawirohardjo.

Sayono, 2010. Buku Ajar Keperawatan Maternitas. Edisi 4. Jakarta: EGC

Setiawan, 2010. Metode Penelitian Kebidanan, Jakarta: Rineka Cipta

Sulistyawati, Dkk. 2010. Asuhan Kebidanan Pada Ibu Bersalin. Jakarta: Salemba Medika

Sumarah, Dkk. 2009. Perawatan Ibu Bersalin. Jakarta: Fitramaya.

Suyanto.\& Salamah, Ummi. 2009. Riset Kebidanan Metodologi \& Aplikasi. Yogjakarta: Mitra Cendikia Press.

Varney. 2008. Buku Saku Kebidanan Edisi Bahasa Indonesia. Jakarta: EGC 